\title{
PEMODELAN REGRESI SPASIAL DEPENDENSI PADA TINGKAT PARTISIASI ANGKATAN KERJA DI INDONESIA TAHUN 2020
}

\section{Regression Modelling with Spatial Dependence on Labor Force Participation Rate in Indonesia 2020}

\author{
Rahmayunda Usali ${ }^{1 *}$, Nurwan ${ }^{2}$, Franky Alfrits Oroh $^{3}$, Muhammad Rezky Friesta Payu ${ }^{4}$ \\ 1,2,3,4 Jurusan Matematika, FMIPA, Universitas Negeri Gorontalo
}

Jln. Prof. Dr. Ing. B. J. Habibie, Tilongkabila, Bone Bolango, 96554, Gorontalo, Indonesia

Corresponding author e-mail: ${ }^{1 *}$ rahmayundausali123@gmail.com

\begin{abstract}
Abstrak
Penelitian ini membahas tentang pemodelan regresi spasial dependensi untuk mengetahui faktor-faktor yang mempengaruhi tingkat partisipasi angkatan kerja di Indonesia tahun 2020. model regresi spasial yang digunakan adalah Spatial Autoregressive Model (SAR) dan Spatial Error Model (SEM). Hasil penelitian memberikan kesimpulan bahwa model SAR lebih baik digunakan dalam pemodelan spasial serta upah minimum provinsi, ratarata lama sekolah dan jumlah penduduk merupakan faktor yang berpengaruh pada tingkat partisipasi angkatan kerja di Indonesia tahun 2020.
\end{abstract}

Kata Kunci : Regresi Spasial, TPAK, SAR, SEM

\begin{abstract}
This study discusses the regression modeling with spatial dependence to determine the factors affecting the labor force participation rate in Indonesia 2020. The spatial regression models used in this study are spatial Autoregressive Model (SAR) and Spatial Error Model (SEM), The finding concludes that the SAR model is better used in spatial modeling. At the same time, provincial minimum wage, the average length of school or educational level, and population are factors that affect the labor force participation rate in Indonesia 2020.
\end{abstract}

Keywords: Spatial Regression, LFPR, SAR, SEM. 


\section{PENDAHULUAN}

Salah satu indikator penting di bidang ketenagakerjaan adalah tingkat partisipasi angkatan kerja. Tingkat Partisipasi Angkatan Kerja (TPAK) adalah situasi yang menggambarkan jumlah angkatan kerja dalam suatu kelompok umur sebagai persentase penduduk dalam kelompok umur tersebut [5]. Penelitian tentang tingkat partisipasi angkatan kerja dan faktor-faktor apa saja yang mempengaruhinya sudah banyak dilakukan tetapi masih sedikit yang memasukkan efek kewilayahan padahal masing masing daerah memiliki karakteristik yang berbeda. Perbedaan yang dimaksud yaitu perbedaan karakteristik sumber daya alam, perbedaan kemampuan sumber daya manusia, dan perbedaan potensi daerah. Menurut data Badan Pusat Statistik (BPS) pada bulan Februari tahun 2020 jumlah angkatan kerja naik 1,73 juta orang dibanding februari 2019. Tetapi berbeda dengan naiknya jumlah angkatan kerja, Tingkat Partisipasi Angkatan Kerja (TPAK) turun sebesar $0,15 \%$ dibanding februari 2019.

Pada data yang melibatkan efek kewilayahan atau lokasi (spasial) itu, model regresi yang cocok digunakan adalah model regresi spasial baik spasial lag maupun spasial error. Regresi spasial merupakan pengembangan dari regresi linear klasik. Pengembangan itu berdasarkan adanya pengaruh lokasi atau spasial pada data yang dianalisis [1].

Data spasial adalah data yang dependen karena data didapatkan dari wilayah spasial yang berbeda sehingga menunjukan adanya ketergantungan antara data dengan wilayah (lokasi) [6]. Pada data spasial, model regresi klasik atau OLS akan menghasilkan kesimpulan yang tidak tepat jika digunakan karena pada analisis model OLS diasumsikan varians error tetap dan tidak ada ketergantungan antar error (autokorelasi) di setiap lokasi pengamatan [6]. Pengujian efek dependensi spasial tidak bisa diabaikan karena dapat menyebabkan estimasi yang tidak efisien dan kesimpulan yang salah atau tidak tepat. Dalam mendeteksi adanya efek dependensi spasial dalam model terdapat beberapa uji yang digunakan yaitu uji Moran's I, dan uji Lagrange Multiplier. Kelebihan dari pengujian statistik uji lagrange multiplier dibandingkan Moran's I adalah dapat lebih spesifik dalam mengidentifikasi efek spasial yang ada, baik efek spasial lag maupun efek spasial error sehingga dalam penelitian ini akan digunakan uji lagrange multiplier dalam mendeteksi ada tidaknya efek dependensi spasial.

Berdasarkan uraian tersebut maka penulis ingin membuat model regresi spasial dependensi pada faktor-faktor yang mempengaruhi tingkat partisipasi angkatan kerja di Indonesia tahun 2020.

\section{METODE PENELITIAN}

Penelitian ini dilakukan selama 4 bulan dimulai sejak bulan Januari 2021 hingga April 2021. Terdapat 1 variabel respon dalam penelitian ini yakni Tingkat Partisipasi Angkatan Kerja dan 6 variabel prediktor yakni Produk Domestik Regional Bruto (PDRB), Indeks Pembangunan Manusia (IPM), Upah Minimum Provinsi (UMP), Rata-rata lama sekolah, persentase penduduk miskin, dan jumlah penduduk. Data pada penelitian ini merupakan data sekunder yang didapat dari website Badan Pusat Statistik (BPS) Indonesia pada tahun 2020. Teknik pengambilan sampel pada penelitian ini menggunakan purposive sampling. Metode analisis yang digunakan yaitu Lagrange Multiplier dan Robust Lagrange Multipler untuk memperoleh model regresi spasial lag dan spasial error.

\section{HASIL DAN PEMBAHASAN}

Penulisan hasil dan Pembahasan dapat dipisahkan dalam sub yang berbeda atau dapat juga digabung menjadi satu sub. Rangkuman hasil yang disajikan dapat dalam bentuk grafik dan angka. Pada bagian hasil dan pembahasan harus bebas dari interpretasi ganda. Pembahasan harus menjawab masalah penelitian, mendukung dan mempertahankan jawaban dengan hasil, membandingkan dengan hasil penelitian yang relevan, nyatakan keterbatasan studi yang dilakukan dan temukan kebaharuan. 


\section{Analisis Deskriptif}

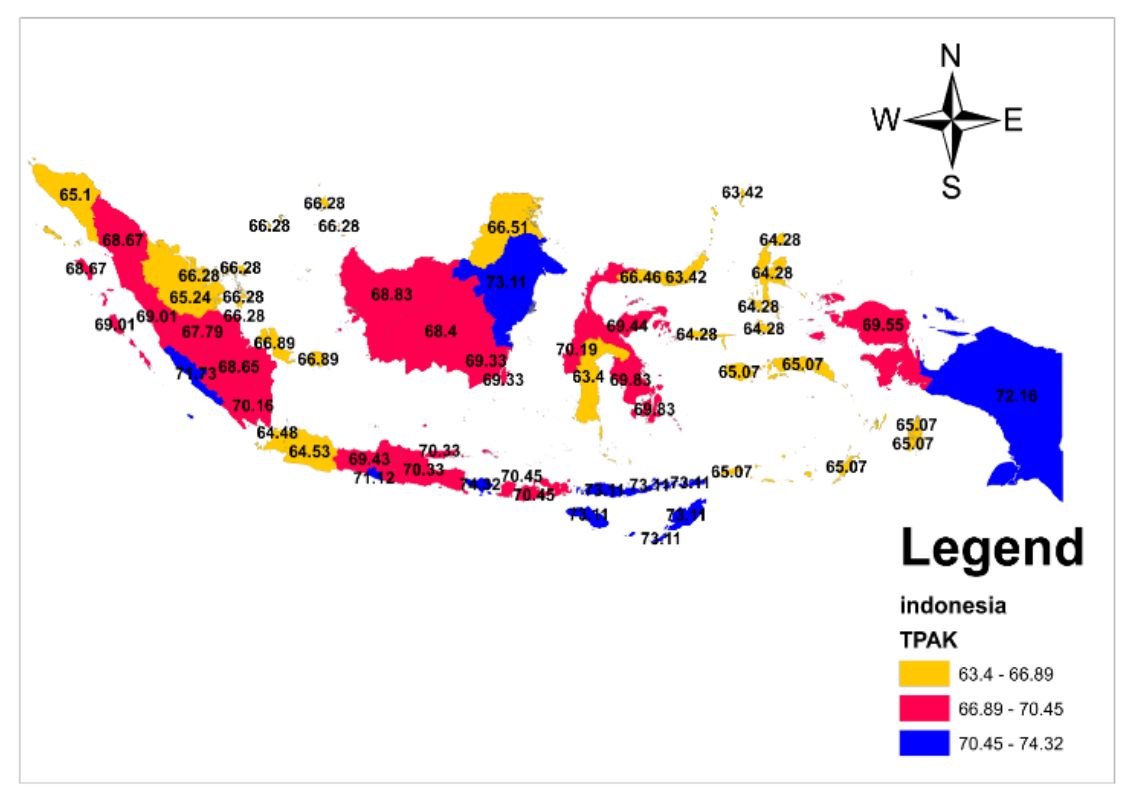

Gambar 1. Data olahan ArcGis TPAK Provinsi di Indonesia tahun 2020

Berdasarkan Gambar 1 dapat diketahui lokasi yang berwarna biru, mengidentifikasikan tingginya TPAK di lokasi tersebut. Terlihat bahwa Provinsi dengan kategori tinggi (70,45-74,32 kasus) terdapat di Provinsi DI Yogyakarta (71,12\%), Provinsi Bengkulu (71,73\%), Provinsi Nusa Tenggara Timur (73,11\%), Provinsi Papua (72,16\%), dan Provinsi Bali $(74,32 \%)$. Sedangkan untuk lokasi yang berwarna kuning menandakan rendahnya TPAK salah satunya adalah Provinsi Maluku $(65,07 \%)$ dan untuk Provinsi Kalimantan Barat $(68,83 \%)$ berwarna merah artinya Provinsi ini dan provinsi lain yang berwarna merah memiliki persentase TPAK sedang. Dengan demikian keberadaan autokorelasi dapat di identifikasi berdasarkan kategori nilai TPAK. Provinsi yang memiliki kategori yang sama mengartikan bahwa provinsi tersebut memiliki persamaan karakteristik.

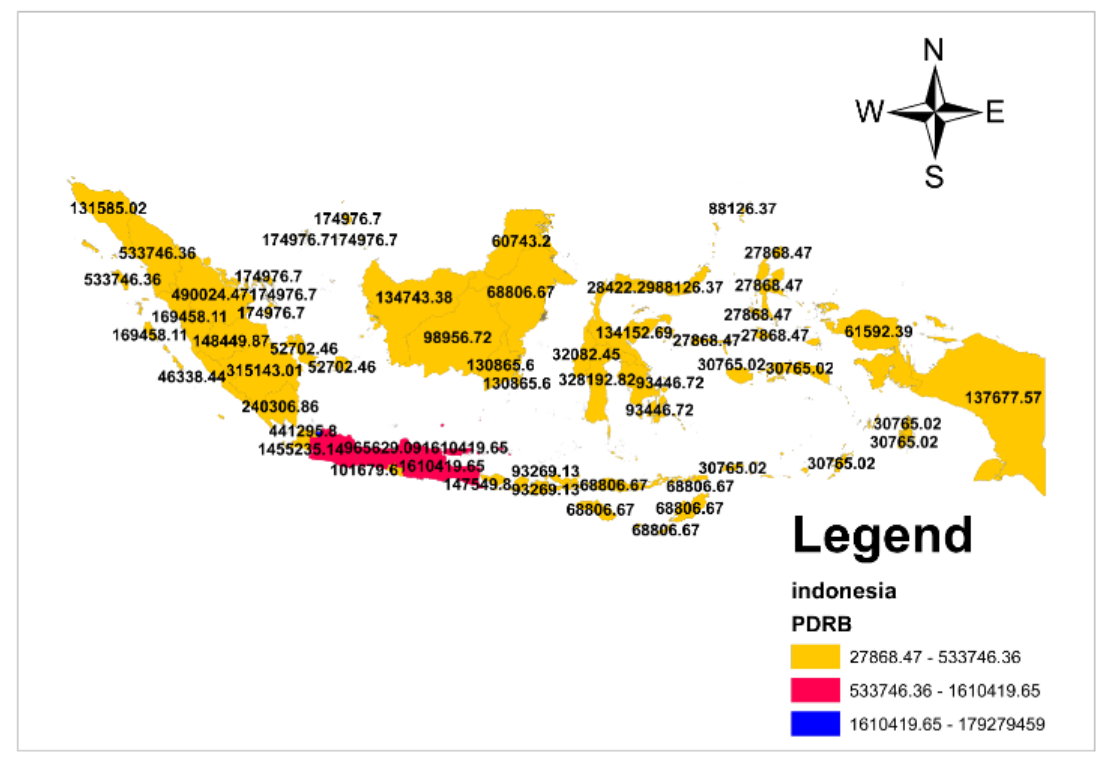

Gambar 2. Data olahan ArcGis PDRB Provinsi di Indonesia tahun 2020

Pada Gambar 2 PDRB tertinggi terdapat di Provinsi DKI Jakarta yaitu 179279459 Milyar Rupiah, PDRB terendah terdapat di Provinsi Maluku Utara yaitu 27868,47 Milyar Rupiah. Secara keseluruhan PDRB Indonesia berada pada kategori rendah yakni berkisar 27868,47 sampai 533746,36 milyar rupiah. 


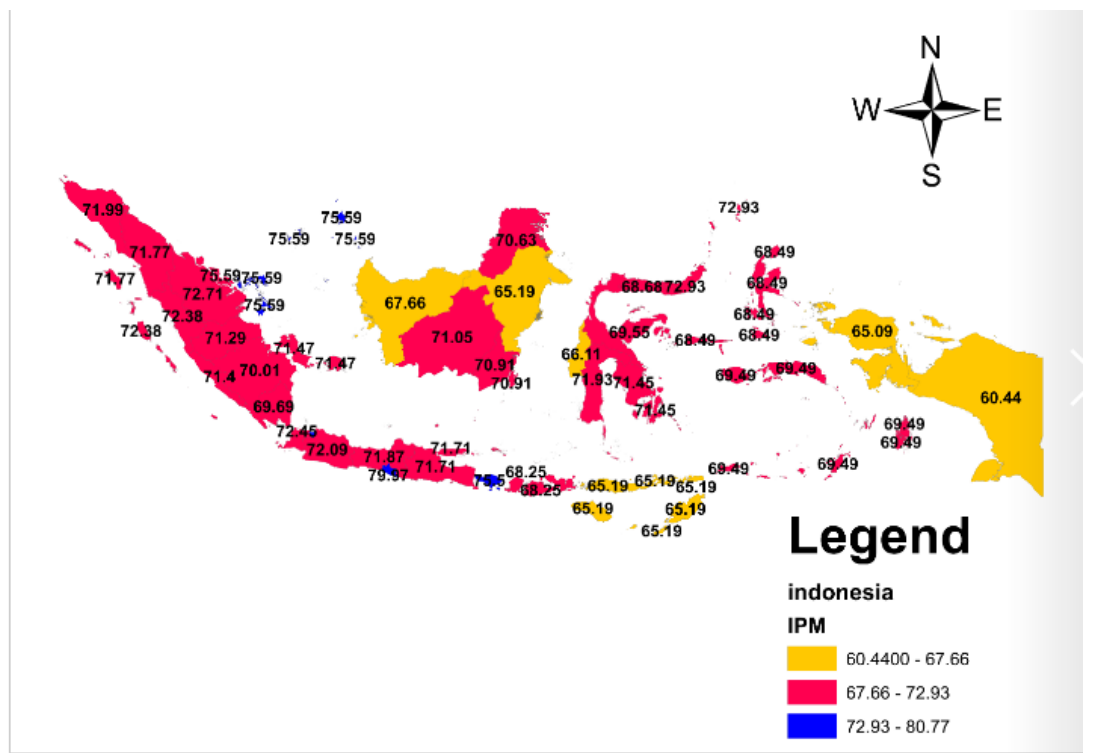

Gambar 3. Data olahan ArcGis IPM Provinsi di Indonesia tahun 2020

IPM tertinggi terdapat di Provinsi DKI Jakarta yaitu 80,77, sedangkan yang terendah terdapat di Provinsi Papua yaitu 60,44. Secara keseluruhan IPM Indonesia berada pada kategori sedang yakni berkisar 67,66 sampai 72,93 .

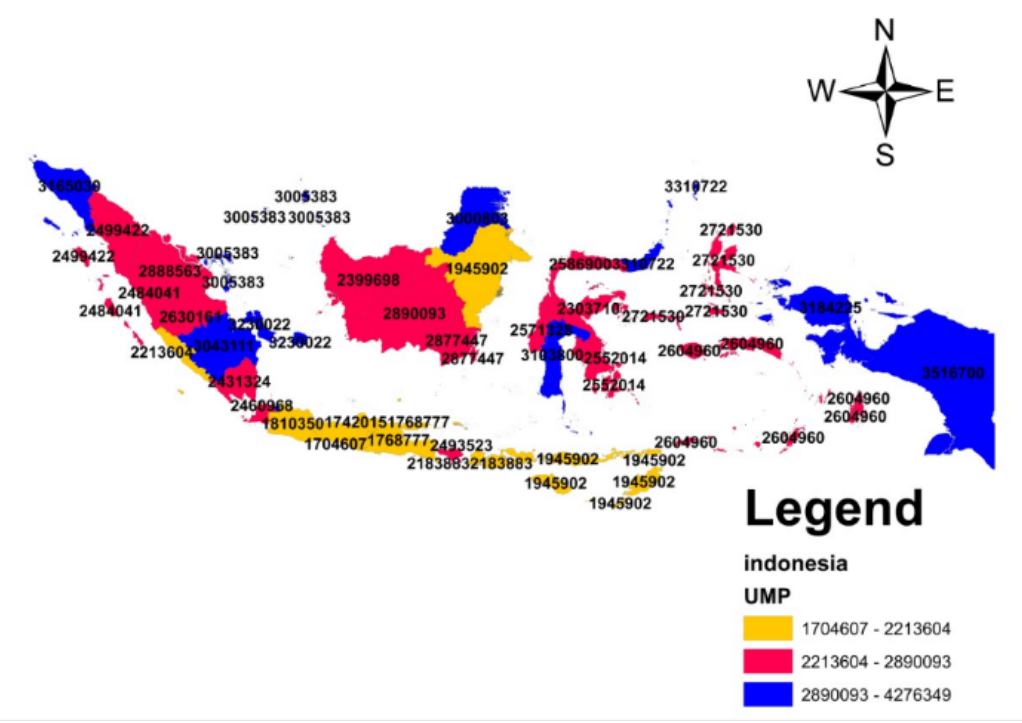

Gambar 4. Data olahan ArcGis UMP Provinsi di Indonesia tahun 2020

UMP tertinggi terdapat di Provinsi DKI Jakarta yaitu 4276349 dan UMP terendah di provinsi DI Yogyakarta yaitu 1704607. Secara keseluruhan UMP Indonesia berada pada kategori sedang yakni berkisar 2213604 sampai 2890093 Rupiah. 


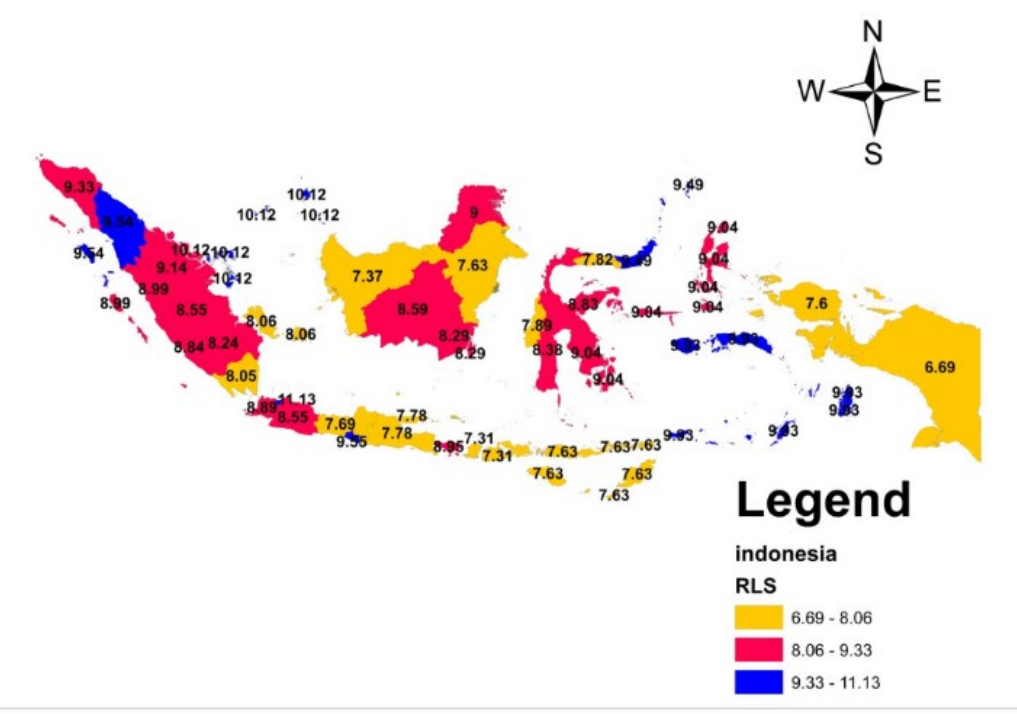

Gambar 5. Data olahan ArcGis RLS Provinsi di Indonesia tahun 2020

RLS tertinggi terdapat pada Provinsi DKI Jakarta yaitu 11,13 tahun, dan RLS terendah terdapat pada provinsi Papua yaitu 6,69 tahun. Secara keseluruhan RLS Indonesia berada pada kategori rendah yakni berkisar 6,69 sampai 8,06 tahun.

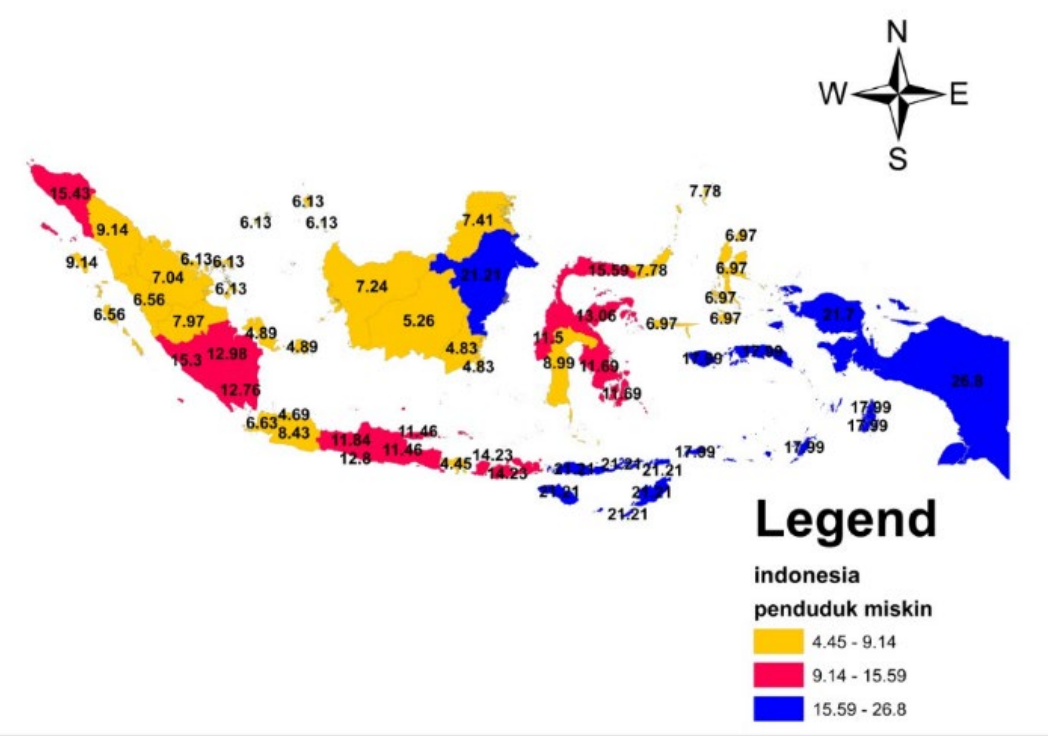

Gambar 6. Data olahan ArcGis Penduduk Miskin Provinsi di Indonesia tahun 2020

Persentase penduduk miskin tertinggi terdapat di provinsi Papua yaitu 26,8\% dan yang terendah terdapat pada provinsi Bali yaitu 4,45\%. Secara keseluruhan persentase penduduk miskin di Indonesia berada pada kategori rendah yakni berkisar 4,45 sampai 9,16 persen. 


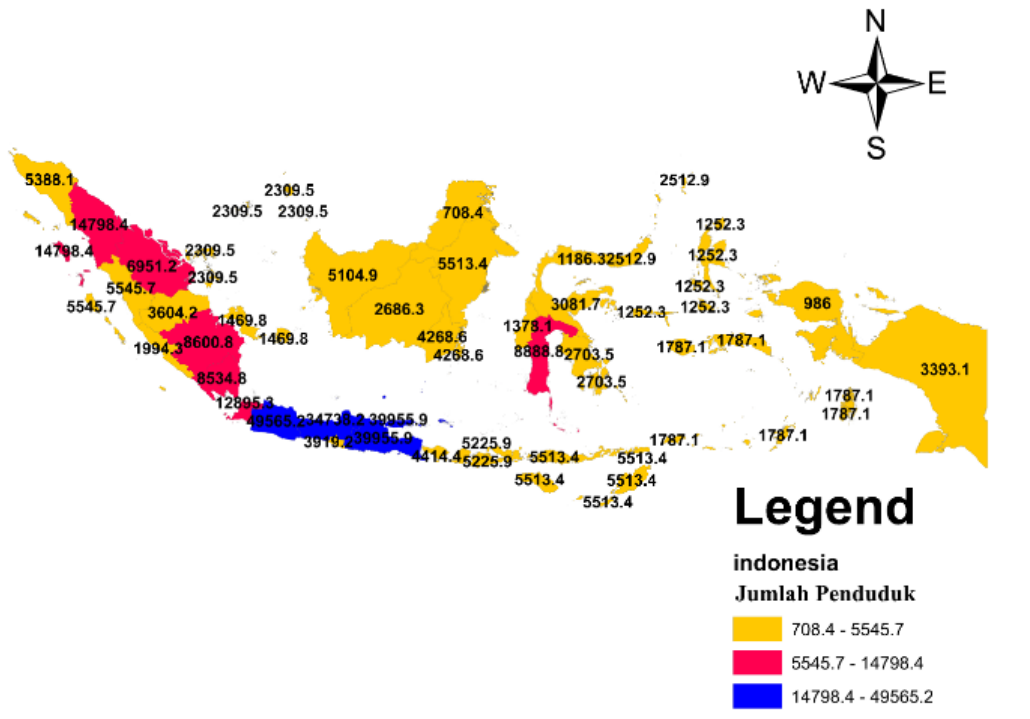

Gambar 7. Data olahan cm ArcGis Jumlah Penduduk Provinsi di Indonesia tahun 2020

Jumlah penduduk tertinggi terdapat di provinsi Jawa Barat yaitu 49565,2 Juta Jiwa dan yang terendah adalah provinsi Kalimantan Utara yaitu 708,4 Juta Jiwa. Secara keseluruhan jumlah penduduk di Indonesia berada pada kategori rendah yakni berkisar 708,4 sampai 5545,7 juta jiwa.

\section{Uji Asumsi Regresi}

\section{Uji Normalitas Residual}

Dalam melakukan uji normalitas residual digunakan bantuan software Minitab. Hasil uji normalitas residual ditampilkan pada Gambar 8, berikut:

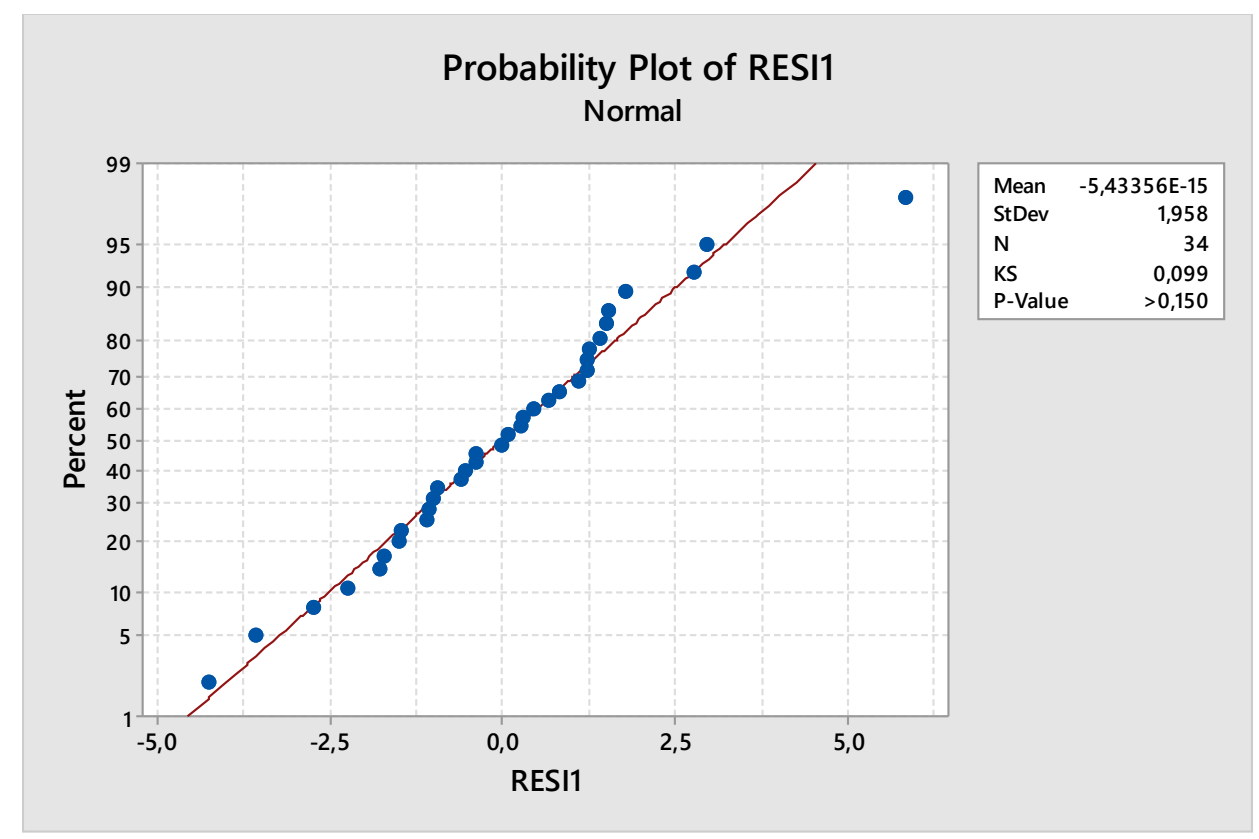

Gambar 8. Uji Normalitas Residual

Berdasarkan Hasil Output Gambar 8 diperoleh nilai statistik uji Kolmogorov-Smirnov 0,099 dengan $\mathrm{P}$-value $>0,150$ sehingga gagal tolak $\mathrm{H}_{0}$ yang berarti residual berdistribusi normal.

\section{Uji Autokorelasi Residual}

Nilai DW yang diperoleh berdasarkan hasil output minitab adalah 2.67910. Nilai DW yang diperoleh akan dibandingkan dengan nilai tabel DW dengan signifikansi 5 \%, jumlah sampel 34 (n) dan jumlah variabel 
prediktor $6(\mathrm{k})$. Dari tabel DW diperoleh nilai $\mathrm{dL}=1,08$ dan nilai $\mathrm{dU}=1,89$. nilai DW 2,67910 lebih besar dari batas bawah (dL) sehingga $\mathrm{H} 0$ diterima yang berarti tidak terdapat autokorelasi pada residual.

\section{Uji Homogenitas Residual}

Uji Glesjer diperoleh dengan meregresikan nilai absolute residual model awal dengan semua variabel prediktor yang digunakan dengan bantuan software minitab. Hasil uji glesjer dapat dilihat pada Tabel 1 .

Tabel 1. Uji Homogenitas Residual.

\begin{tabular}{ll}
\hline Source & P-value \\
\hline Regression & 0,970 \\
\hline PDRB & 0,364 \\
\hline UMP & 0,747 \\
\hline IPM & 0,700 \\
\hline RLS & 0,606 \\
\hline Penduduk miskin & 0,830 \\
\hline Jumlah Penduduk & 0,824 \\
\hline
\end{tabular}

Dari hasil pengujian diperoleh bahwa semua variabel memiliki nilai p-value $>\alpha=0,05$ sehingga $\mathrm{H}_{0}$ diterima yang berarti residual homogen.

\section{Uji Multikolinearitas}

Berdasarkan output minitab, hasil pengujian multikolinearitas dapat dilihat pada Tabel 2

Tabel 2. Uji Multikolinearitas

\begin{tabular}{ccc}
\hline Term & P-Value & VIF \\
\hline Constant & 0,000 & \\
\hline PDRB & 0,156 & 2,11 \\
\hline UMP & 0,006 & 2,32 \\
\hline IPM & 0,228 & 4,65 \\
\hline RLS & 0,010 & 3,40 \\
\hline Penduduk Miskin & 0,155 & 1,89 \\
\hline Jumlah Penduduk & 0,008 & 1,60 \\
\hline
\end{tabular}

Pada Tabel 2, dapat dilihat semua Variabel memili nilai VIF yang kurang dari 10, hal ini berarti tidak terdapat multikolinearitas antar variabel prediktor.

Berdasarkan hasil uji asumsi regresi diperoleh bahwa residual berdistribusi normal, identik, dan independen. Hal ini berarti semua asumsi untuk model OLS terpenuhi.

\section{Matriks Pembobot Spasial}

Dengan memperhatikan hubungan ketetanggaan dan jarak maka digunakan queen contiguity yaitu persinggungan sisi-sudut serta melihat bagaimana suatu penduduk berpindah atau berinteraksi langsung dengan penduduk yang berada di daerah/lokasi lain yang bertetanggaan langsung, untuk itu diberikan bobot spasial W dengan:

$$
W_{i j} \begin{cases}1 & \text { jika } i \text { dan } j \text { saling berdekatan } \\ 0 & \text { untuk yang tidak berdekatan }\end{cases}
$$

dimana $i$ dan $j$ merupakan daerah atau lokasi yang diamati. Maka diperoleh matriks pembobot spasial $\mathrm{W}$,

$$
\left[\begin{array}{ccccccccc}
0 & 0 & 0 & 0 & 0 & 0 & 0 & \cdots & 1 \\
0 & 0 & 0 & 0 & 0 & 0 & 0 & \cdots & 0 \\
0 & 0 & 0 & 0 & 1 & 0 & 0 & \cdots & 0 \\
0 & 0 & 0 & 0 & 0 & 0 & 1 & \cdots & 0 \\
0 & 0 & 0 & 0 & 0 & 0 & 0 & \cdots & 0 \\
\vdots & \vdots & \vdots & \vdots & \vdots & \vdots & \vdots & \ddots & \vdots \\
0 & 0 & 0 & 0 & 0 & 1 & 0 & \cdots & 0
\end{array}\right]
$$




\section{Uji Lagrange Multiplier}

Uji Lagrange Multiplier digunakan untuk melihat adanya efek dependensi spasial atau autokorelasi spasial pada data sehingga pemodelan dengan regresi spasial dapat dilakukan. Hasil uji Lagrange Multiplier dapat dilihat pada Tabel 3.

Tabel 3. Uji Lagrange Multiplier

\begin{tabular}{cc}
\hline Statistic Parameter & P-value \\
\hline Lagrange Multiplier (Error) & 0,334060 \\
\hline Lagrange Multiplier (Lag) & 0,005786 \\
\hline
\end{tabular}

Dari hasil uji LM pada lag dan error diperoleh nilai p-value untuk error 0,334060 artinya $\mathrm{H}_{0}$ diterima pada taraf signifikansi 5\% sehingga tidak ada dependensi atau autokorelasi spasial pada error. Sedangkan nilai $\mathrm{p}$-value untul lag 0,005786 atinya tolak $\mathrm{H}_{0}$ pada taraf signifikansi 5\% sehingga ada dependensi spasial pada lag. Dependensi spasial pada lag menandakan analisis dapat dilanjutkan dengan model regresi spasil SAR.

\section{Uji Robust Lagrange Multiplier}

Uji RLM digunakan untuk meyakinkan adanya efek dependensi spasil pada Lag. Hasil uji RLM dapat dilihat pada Tabel 4.

Tabel 4. Uji Robust Lagrange Multiplier

\begin{tabular}{cc}
\hline Statistic Parameter & P-value \\
\hline Robust Lagrange Multiplier (Error) & 0,391827 \\
\hline Robust Lagrange Multiplier (Lag) & 0,006465 \\
\hline
\end{tabular}

Dari hasil uji RLM pada lag dan error diperoleh nilai p-value untuk error 0,391827 artinya H0 diterima pada taraf signifikansi 5\% sehingga tidak ada dependensi atau autokorelasi spasial pada error. Sedangkan nilai p-value untul lag 0,006465 atinya tolak H0 pada taraf signifikansi 5\% sehingga terbukti ada dependensi spasial pada lag.

\section{Spatial Autoregressive Model (SAR)}

Berdasarkan hasil uji lagrange multiplier diperoleh LM lag signifikan sehingga model yang cocok adalah model SAR. Estimasi parameter SAR dapat dilihat pada Tabel 5

Tabel 5. Spatial Autoregressive Model

\begin{tabular}{cccc}
\hline Parameter & Estimasi & Zhitung & P-value \\
\hline$\rho$ & $-0,012319$ & 3,1059 & 0,078009 \\
\hline$\beta_{0}$ & 10,58608465 & 23,897 & $2,2.10^{-16}$ \\
\hline$\beta_{2}$ & $-0,00050064$ & $-3,3018$ & 0,0009607 \\
\hline$\beta_{4}$ & $-0,46041483$ & $-3,1758$ & 0,0014941 \\
\hline$\beta_{6}$ & $-0,00118198$ & $-2,2271$ & 0,0259378 \\
\hline \multicolumn{4}{c}{ AIC } \\
\hline
\end{tabular}

Dari Tabel 5. dapat terbentuk model SAR yang dituliskan dalam persamaan 1:

$$
\widehat{y_{l}}=-0,0123 \sum_{j=1, i \neq j}^{34} W_{i j} y_{j}+10,586-0,0005 X_{2 i}-0,460 X_{4 i}-0,001
$$

Dari model SAR pada Persamaan 3.1, dapat diinterpretasikan:

Apabila Upah Minimum Provinsi bertambah sebanyak satu Rupiah maka akan cenderung berkurang jumlah Tingkat Partisipasi angkatan Kerja di Indonesia sebanyak 0,00050064 persen dengan asumsi variabel lain konstan.

Dari hasil penelitian yang diperoleh menunjukan hasil yang selaras dengan teori yang dikemukakan Todaro (2000) yang mengatakan bahwa semakin tinggi tingkat upah yang ditawarkan kepada tenaga kerja 
akan menurunkan tingkat penyerapan tenaga kerja. Hasil penelitian ini juga didukung oleh studi yang dilakukan Arizka Sofiyana Maharani (2017), Munir Ikhsan (2016) dan sulistiawati (2012) yang menemukan bahwa upah minimum mempunyai hubungan yang negatif dan signifikan terhadap tingkat partisipasi angkatan kerja. Hal ini dapat disebabkan oleh faktor lain berupa kurangnya keterampilan kerja, terjadinya Pemutusan Hubungan Kerja (PHK) dan pemberian upah yang semakin tinggi dapat lebih mengintensifkan produktivitas perorangan karyawannya, sehingga tidak diperlukan lagi penambahan karyawan. Akhirnya tidak adanya peningkatan jumlah angkatan kerja pada waktu tersebut.

Apabila Rata-rata lama sekolah bertambah sebanyak satu tahun maka akan cenderung berkurang jumlah Tingkat Partisipasi angkatan Kerja di Indonesia sebanyak 0,46041483 persen dengan asumsi variabel lain konstan. Hasil penelitian ini didukung oleh studi yang dilakukan oleh Kadek Borgan Bonerri (2018) yang menunjukan bahwa rata-rata lama sekolah mempunyai hubungan yang negatif dan signifikan terhadap tingkat partisipasi angkatan kerja. Adanya pengaruh negatif bisa disebabkan karena banyaknya penduduk usia kerja yang memutuskan untuk tidak langsung masuk ke pasar kerja melaikan memilih untuk melanjutkan sekolah mereka. Hal ini juga sesuai dengan pendapat simanjuntak (2001) yang mengatakan bahwa semakin besar jumlah penduduk yang besekolah akan menurukan tingkat partisipasi angkatan kerja. Penduduk dengan tingkat pendidikan yang tinggi akan lebih memilih pekerjaan yang sesuai dengan pendidikan mereka. Namun di negara berkembang terkadang keinginan tersebut tidak diiringi dengan peningkatan kemampuan dari pemberi kerja.

Apabila Jumlah penduduk bertambah sebanyak satu jiwa maka akan cenderung berkurang jumlah Tingkat Partisipasi angkatan Kerja di Indonesia sebanyak 0,00118198 persen dengan asumsi variabel lain konstan. Berkurangnya TPAK ini dapat di sebabkan oleh ketidakseimbangan antara jumlah penduduk dan lapangan pekerjaan yang tersedia, hal ini didukung oleh pendapat Subandi (2011) yang mengatakan bahwa Jika dalam suatu wilayah memiliki penduduk yang lebih banyak daripada lapangan pekerjaan, maka akan mendorong peningkatan terhadap pengangguran sehingga lowongan yang tersedia tidak sesuai dengan pertambahan penduduk yang ada.

\section{KESIMPULAN}

Dari hasil analisis dan pembahasan yang telah dilakukan dapat disimpulkan:

Dalam menentukan model faktor-faktor yang mempengaruhi Tingkat Partisipasi Angkatan Kerja di Indonesia, berdasarkan Uji Lagrange Multiplier diperoleh nilai LM lag signifikan sehingga model SAR lebih baik digunakan dalam pemodelan spasial. Faktor-faktor yang secara signifikan mempengaruhi Tingkat Partisipasi Angkatan Kerja adalah Upah minimum Provinsi, Rata-rata lama sekolah, dan Jumlah Penduduk.

\section{DAFTAR PUSTAKA}

[1] A. P. Mangkunegara, "Evaluasi Kinerja Sumber Daya Manusia.” Refika Aditama, Bandung, 2005.

[2] A. S. Fotheringham and P. A. Rogerson, The SAGE Handbook of Spatial Analysis. SAGE Publications, 2008.

[3] D. Mahsunah, "Analisis Pengaruh Jumlah Penduduk, Pendidikan Dan Pengangguran Terhadap Kemiskinan Di Jawa Timur," J. Pendidik. Ekon., vol. 1, no. 3, pp. 1-17, 2013.

[4] D. W. W. John E. Hanke, Business Forecasting, 9th ed. New Jersey: Pearson Prentice Hall, 2009.

[5] E. D. Astuti, "Consumptive behavior in buying goods from housewives in Samarinda City," eJournal Psikol., vol. 1, no. 2, pp. 148-156, 2013.

[6] I. R. A. Tria Susilowati Mahading, Resmawan, Lailany Yahya, "METODE SPATIAL AUTOREGRESSIVE DALAM ANALISIS," vol. 5, no. 2, pp. 9-19, 2020.

[7] J. P. LeSage, “An introduction to spatial econometrics," Rev. d'Economie Ind., vol. 123, no. 3, pp. 19-44, 2008, doi: 10.4000/rei.3887.

[8] L. Anselin, Spatial Econometrics: Methods and Models. Springer Netherlands, 2013.

[9] M. C. Prof. Dr. H. Imam Ghozali, Aplikasi Analisis Multivariate Dengan Program IBM SPSS19, Edisi 5. BP Universanitas Diponegoro, 2011.

[10] M. dan M. D.R, Pembangunan Ekonomi Berwawasan Lingkungan. Malang: Universitas Negeri Malang, 2011.

[11] M. Kara, "Konstribusi Pembiayaan Perbankan Syariah Terhadap Pengembangan Usaha Mikro Kecil Dan Menengah (UMKM) di Kota Makassar," Ilmu Syariah dan Huk., vol. 47, no. 1, pp. 315-322, 2013.

[12] M. L. Jhingan, Ekonomi Pembangunan dan Perencanaan. Jakarta Timur: Rajawali Pers, 2012.

[13] M. P. Todaro, Economic development in the third world, Cet. 4. Erlangga. 1994

[14] Mulyadi, Ekonomi sumber daya manusia dalam perspektif pembangunan. Jakarta: Raja Grafindo Persada, 2003.

[15] N. Cressie, Statistics for Spatial Data. Wiley, 2015. 
